\title{
電子教科書の規格とEDUPUBの現状
}

\section{Digital textbook specifications and EDUPUB}

田村 恭久 ${ }^{1}$

\section{TAMURA Yasuhisa ${ }^{1}$}

1 上智大学 理工学部（干102-0081 東京都千代田区四番町4-7) E-mail:ytamura@sophia.ac.jp

1 Sophia University, Faculty of Science and Engineering (Yonbancho 4-7 Chiyoda-ku, Tokyo 102-0081)

原稿受理 (2014-12-04)

情報管理５7(11), 791-798, doi: 10.1241/johokanri.57.791 (http://dx.doi.org/10.1241/johokanri.57.791)

著者抄録

電子教科書に関する規格策定の動きと，その中の１つである EDUPUB の概要を紹介する。標準規格を策定することで， 開発者側にも利用者側にもメリットが生まれ，新たな企業の参入を促すことができる。IEEE，CEN，IMS などが電子教 科書の規格策定に動いているが，IDPF，IMS GLC，W3C が共同で開発を進めている EDUPUB は対象範囲が広く，かつ 実装可能性を高めるために既存規格を極力利用している。また議論中のものも含めてオープンな仕様であり，採用す るための参入障壁が低いため，今後有力なフォーラム標準となりうる。ただし，EDUPUBの規格策定は現在進行中で あり，今後内容を修正あるいは拡大する可能性がある。

キーワード

EDUPUB，電子教科書，標準規格，フォーラム標準，IDPF，IMS GLC，W3C，IEEE，CEN

1.はじめに

本稿では，電子教科書の規格と，その1つである EDUPUBの現状を紹介する。前稿1)では，各国の電子 教科書の導入状況，導入の是非をめぐる議論，各種 プラットフォームの比較などを紹介した。これに対 し，本稿はより技術的な議論に踏み込みたい。

「電子教科書」という言葉が包含する範囲は，場面 によってさまざまである。

たとえば，次のようなものがある。

（1）紙媒体の教科書を電子メディア化したもの

（2）（1）に参考書や辞書などを加えたもの(「教科書・
教材」ともいう)

（3）（2）に外部の教材や問題, ノート，LMS (Learning Management System）上の情報を含めたもの

（4）（3）に学務情報管理，認証，学習履歴分析など の各種サービスを加えた電子教科書のサービス 全体

本稿で「電子教科書」という場合，おおむね上記 の（3）の範囲をカバーする，広いものととらえていた だきたい。

教科書，参考書，辞書，ノートなどの紙媒体を ノートPCやタブレットPCに載せて閲覧・使用するた め，これまでさまざまな技術規格が提案されてきた。 
2000年代には，ベンダ一固有の，仕様が公開されて いないファイル形式で電子教科書を作成・配信する 例が多く見受けられた。これに対し，2010年代に入 ると，ベンダー固有ではなく仕様が公開されている ファイル形式，また無料で利用可能なものを利用す る傾向が強まっている。これらのうち，前稿1)では， PDF，HTML，Flashなどの仕様を簡単に紹介した。

ここで，こういった仕様を一般に利用可能とする 標準規格について触れる。一般論として，これらの 標準規格には次の3種類がある注1)。

（1）デジュール（De Jure）標準：ISO，JIS，ITUな ぞの公的機関において，公的で明文化され公開 された手続きによって作成された標準

（2）フォーラム（Forum）標準：IEEEやIDPFなど， 関心のある企業等が集まってフォーラムを結成 して作成した標準

（3）デファクト（De Facto）標準：個別企業等の標 準が，市場の取捨選択・淘汰によって市場で支 配的になり業界の標準団体や国際機関の承認の 有無にかかわらず，事実上の標準となったもの

こういった標準規格を策定することで，次のよう なメリットを得ることができる注2)。

（1）ビジネスの視点：標準化を事業戦略ツールと して利用し，市場の創出／拡大，コストダウン 等により，利益の追求を図ること

（2）消費者・顧客の視点：標準化により製品やサー ビス内容を明確に表示し，消費者・顧客が適切 かつ誤解なくそれらを選定できるようにするこ とで，顧客満足度を向上すること

（3）産業・社会など公的な視点：公正な競争や貿 易の壁を排除することによる社会・産業全体の 発展を目指し，社会に貢献すること

これを，電子教科書に適用すると，次のようなメ リットとして具体的にあげることができる。

（1）ビジネスの視点：電子教科書のファイル形式 を統一することにより，編集環境や操作環境を 開発する工数を削減し，コストダウンが図れる。
また，仕様が国際標準化されれば，これを用い た教育・学習サービスの輸出機会が生まれる。

（2）教員や学習者の視点: 操作方法やファイル形 式が定まることにより，操作の混乱を防げる。ま た，どのOSでも閲覧・操作できる教科書であれ ば，学習者用PCの選択の幅が広がり，結果とし てTCO (Total Cost of Ownership) が低減できる。

（3）産業・社会など公的な視点：認証，参照教材， 学習記録分析などのさまざまなサービスに対す るインターフェースが標準化されることにより， 多くの企業の参入機会が拡大し，公正な競争が 保たれる。

こういった背景をもとに，現在世界各国で電子教 科書の技術仕様を策定し，また標準化する動きがあ る。これらは，主に次の項目を対象としている。

・内容のデータ形式，メタデータ形式

・交換するデータの形式やプロトコル

・最低限の機能

・多様な学習形態を提供するための機能

これらは，主に電子教科書の技術的な仕様に着目 している。一方で，教科書が使われる教育現場の活 動が，仕様や標準によって制限されることがあって はならない。このため，次の項目は標準化作業の対 象外である。

・学習指導要領，カリキュラム

・学習方法, 教授法

・教員独自の授業ノウハウや工夫

・教科書・参考書・辞書・ドリルの出版社

なお一般論として，標準化はメリットだけではな くデメリットもあることが知られている。本稿では この議論は割愛させていただく。詳細は金2) の議論 などを参照いただきたい。

以降，2章ではさまざまな団体で行われている電子 教科書の標準仕様の状況を紹介し，3章ではその中の EDUPUBに焦点を当てる。なお，EDUPUBの基礎となっ ているEPUB標準規格については，村田3)，高瀬4)の 紹介を併せて参照いただきたい。 


\section{2. 電子教科書のフォーラム標準}

現在，電子教科書のフォーラム標準を策定する活 動がいくつかあり，これらを紹介する。なお，現時 点では電子教科書のデジュール標準は存在せず，ま たデファクト標準と呼べるほど市場シェアが高いも のも存在しない。

\subsection{IEEE Actionable Data Bookプロジェクト}

IEEE (The Institute of Electrical and Electronics Engineers) 注3) は，米国に本部を置く電気電子技術 者の協会である。このLTSC (Learning Technology Standards Committee) が，2011年からActionable Data Book（ADBook）と呼ぶ仕様を検討中である5)。

ADBookは，理数系教育（STM Education）をもサ ポートする電子教科書の仕様として議論がスタート し，以下の特徵を目標としている。

- IDPF (International Digital Publishing Forum) 注4) が規定したEPUB電子書籍を基本とする。

・Experience API注5) など公開されている既存規格 を利用する。

・学習者のアクセシビリティーと学習スタイルな どの学習者特性をサポートする。

・対話的なコンテンツをサポートする。

・操作デバイスと外部サーバー（クラウドベース のLMS，学習記録サーバ一など）との情報交換 を可能とする。

・この情報交換にはExperience APIの利用を勧める。

・コンテンツリポジトリ（教材などの蓄積サー バー）からの教材取得を可能とする。

・カメラ，GPSセンサー，実験計測センサーなどの 情報を利用し，理数系教育をサポートする。

ADBookプロジェクトは，現在いくつかの報告書を 公表しているのみで，仕様書や実装例は公開されて いない。2015年に技術フレームワークやユースケー スを公開する予定である注6)。

\subsection{CEN eTernityプロジェクト}

CEN (European Committee for Standardization) 注7) は， ヨーロッパの標準化団体である。この中で，eTernityプ ロジェクト注8) が2012年に発足し，電子教科書に関す る技術仕様についての調査が進められている。機器の 紹介や機能・性能についての調査が多く，具体的な電 子教科書の仕様には至っていないが，EPUB3をべース とする勧告が出される予定である。

\subsection{IMS ICEプロジェクト}

IMS GLC (Global Learning Consortium) 注9) は，米 国を中心とするeラーニングの団体であり，QTI（後述） などのフォーラム標準の策定や教育の情報化の普及 啓蒙活動を幅広く行っている。教育の情報化に関する 雑誌の発刊や国際会議を主催するEDUCAUSE注10) とも 深く連携している。このIMSが, 2013年にICE (Interactive \& Connected Educational e-Book) プロジェクト注11) を発足させた。情報は会員外には公開されていないが， IMSは現在，後述するEDUPUBプロジェクトに参加し ており，それに人員を割いているようである。

\subsection{EDUPUBプロジェクト}

EDUPUBプロジェクトは，IDPF，IMS GLC，W3C (World Wide Web Consortium) 注12) の3団体が中心と なる，電子教科書の標準規格を策定するプロジェク トである。2013年10月に発足し，以下の会議を行っ ている。

・2013年10月 ボストン注13)

・2014年2月 ソルトレイク注14)

・2014年6月 オスロ注15)

-2014年9月 東京注16)

具体的な議論・検討は電話会議で毎週行われる。 参加はオープンで，希望者には事前に開催通知のメー ルが届く。

EDUPUBは上記の3団体のほかに，Pearsonなどの出 版社も参加し，自社の電子教科書の仕様を公開する などの貢献を行っている。日本からもベネッセが仕 
様を提案している。

次章では，このEDUPUBの仕様の範囲や，現在議論 されている仕様の概要を紹介する。

\section{EDUPUB仕様の概要}

EDUPUBが対象としている範囲は，おおむね図1の とおりである。以下，図1の (a)〜 (i) に示す仕様の概 要を紹介する。なお，以下は現時点での範囲や内容 であり，今後の議論によって拡大・変更される可能 性がある。

\subsection{EPUB3に含まれる仕様}

電子教科書のフォーラム標準として議論されてい るEDUPUBは，IDPFが策定したEPUB3を拡張する。こ のEPUB3は，次の特徵をもつ。

・HTMLがサポートする画像ファイルのほか，SVG 形式の画像も表示可能

・CSSによるレイアウト制御が可能

・文字の拡大縮小や行間変更などができ，それに 合わせて1行の文字数が自動的に变更されるリフ ロー表示を許す
・縦書き，禁則処理，ルビなどの言語依存表示に 対応

・識字障がい者向けのDAISY仕様を包含

なお，EPUB3は現在IDPFのフォーラム標準であり， ISO/IEC JTC1/SC34においてデジュール標準とするた めの議論が開始されている。

\section{2 電子教科書内容のタグ付け}

教科書の本文などは，書籍における章節見出し， 注釈，目次などの項目のほかに，「学習目標」「演習 問題」「ヒント」「解答」「フィードバック」など，教 科書特有の記述を含んでいる（図1 (a))。これらの記 述を機械的に意味付けするため，EDUPUBではEPUB3 に加えて新しいタグを規定している。この仕様は EPUB3 EDUPUB Profileと呼ばれ，現在パブリックコ メント募集のため公開されている注17)。

\section{3 教科書のメタデータ（説明情報）}

教科書には本文やメディアがあるほか，その属 性を説明するメタデータが付属していると便利で ある。書籍に付与されるメタデータの例としては Dublin Core注18) があり (ISO 15836注19) として

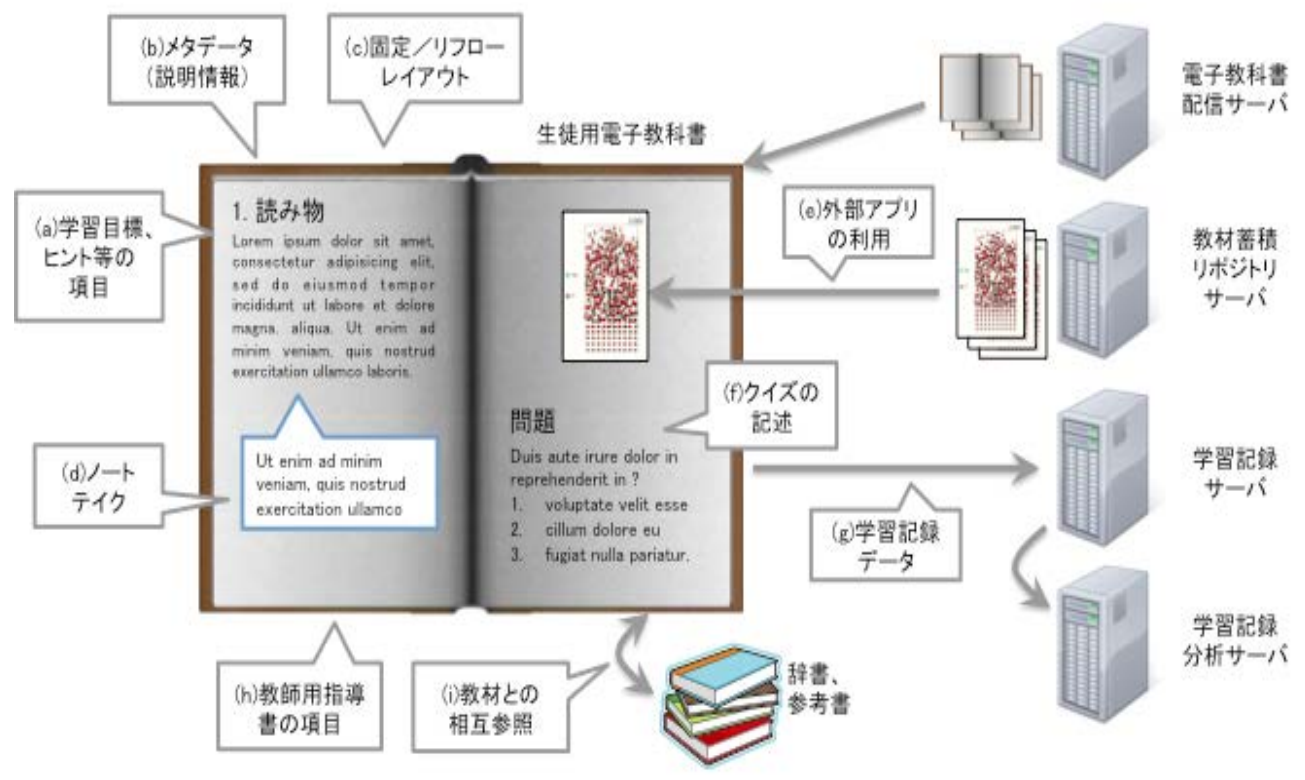

図1ＥDUPUBの仕様範囲 
デジュール標準となっている)，Title，Creator， Subject, Publisher, Date, Language, Rightsなどの 項目を備える。書籍を検索する際，書籍の本文を検 索するよりメタデータを検索対象とすることで，よ り正確に検索が行える。

一方，電子教材に対するメタデータとしては， IEEEがLOM（Learning Object Metadata）規格を 1484.12.1-2002注20) として，またIMSがLRM（Learning Resource Meta-data) 注21) 規格を，LRMI (Learning Resource Metadata Initiative) 注22) がLRMI規格を規定 している。EDUPUBプロジェクトでは，LRMIが電子 教科書のメタデータ策定を担当している（図1 (b))。

また，電子教科書のメタデータはアクセシビリ ティーの項目，たとえば，教科書を使用する学習者 にある障がいの種類や程度を含めることが望まし い。これにより，それぞれの障がいに応じた電子教 科書を検索する助けとなる。これについても，IDPF， IMS，LRMIの三者で協議が始まっている。

\section{4 紙面のレイアウト}

EPUBは，表示する文字を拡大表示できるリフロー 表示を許している。電子教科書をリフロー表示する と，弱視の学習者にとつて文字が読みやすくなり，従 来の紙媒体の拡大教科書が不要となる場合がある。 このメリットがある一方で，リフロー表示が問題と なる場合もある。特に日本の初等教育の教科書では， ページ内の文字の段落や画像などが特定位置に置か れるような，固定レイアウトを想定して組版するケー スが多い。この電子教科書をリフロー表示すると想 定した版組が崩れ，授業で教員がページを指定する 際に不具合が起こるなどの問題が生じる。

この問題を解決するため，IDPFではEPUB MultipleRendition Publications 注23) と呼ぶ規格を策定中であ る。これは, 単一の電子書籍ファイルの中に, リフロー 表示する内容と固定レイアウトの内容の両者を備え， スイッチによってリフローと固定の表示を切り替え ることができるものである（図1 (c)）。

\section{5 ノートテイク}

学習の現場では，単に教科書を見るだけでなく， 学習者が気づいたことをノートに書くノートテイク 作業が頻繁に発生する。この作業をパソコンで行う 場合，いくつかの実現方法がある。IDPFでは，W3C が策定したOpen Annotation Data Model注24) を拡張 したOpen Annotation in EPUB注25) を提案している。 Open Annotation Data Modelは, Webコンテンツ に対して注釈 (Annotation) を追加するための規格 である。Open Annotation in EPUBはこれを拡張し， EPUB電子書籍の任意の場所に注瀵を追加・修正する ことができる（図1 (d))。学習者がノートとして追加 した注釈をファイルやデバイスのどこに格納するか は実装の問題であり，上記の規格では特に規定され ていない。

\section{6 外部の教材やアプリの利用}

電子教科書をEPUB3で実現した場合，画像などの基 本的なメディアは表示できるが，3Dメディアや複雑 な対話型メディアは表示できない場合がある。また， EPUB3はJavaScriptを用いた対話型機能の記述を禁止 してはいないが, EPUBのバージョン, EPUBビューアー (表示ソフトウェア)，OSなどのバリエーションがあ り，JavaScriptの動作は必ずしも保証されていない。 このため，3Dメディアなどの先進的なメディアを 電子教科書で使用する場合，適切なメディアやアプ リケーションを外部から転送し，表示することが望 ましい。これを実現するため，IMSはLTI (Learning Tools Interoperability) 注26) という規格を策定してい る (図1 (e))。

\section{7 クイズ}

多肢選択式， $\bigcirc \times$ 式，組み合わせ式，穴埋め式など， クイズには多様な形式がある。また，上位のクイズ でこの選択肢を選んだ場合，下位のクイズでこちら を表示するなど，複数のクイズ間に因果関係をもた せると効果的な場合もある（図1 (f))。 
こういったクイズを記述する規格として，IMSは QTI（Question \& Test Interoperability）と呼ぶ規格を 提案している注27)。QTIはXMLでクイズを記述し，か つ上記のような多様なクイズのバリエーションを記 述できるよう，巨大な規格となっており，その解釈 や表示に複雑な処理系が必要となる。このためIMSは， 現在QTIの次期バージョンとしてaQTIと呼ぶ規格を策 定中である。

\section{8 学習記録データ}

電子教科書を表示・操作するデバイスでは，さま ざまな学習活動の記録データが取得可能である。学 習活動の記録はLMSの教材をWebブラウザーで閲覧 する際にも，教材のアクセスやクイズ，課題の解答 を取得していた。こういつた情報に加え，タブレッ トPCやノートPC上で教科書を表示・閲覧する際，ペー ジめくりや移動の情報は容易に取得できる。また， タブレットPCがもつ多様なセンサーを用いると，上 記以外のさまざまな情報も取得できる。これらの学 習記録データは，LRS (Learning Record Store) と呼 ぶサーバーに蓄積され，時系列や相関などが分析さ れる。こういった活動全般をLearning Analytics (LA)， あるいは教育ビッグデータ分析と呼んでいる（図1 (g))。

LAを実施するフレームワークとして，IMSはCaliper Analytics Framework注28) を提唱している。LAを行う ための構成要素，ステークホルダー（利害関係者）， データの流れなどを示すフレームワークがあり，ま た具体的に取得すべきデータ項目の例をあげている。

この一方で，IDPFでEDUPUB Structural Semantics Vocabulary for Learning Analyticsと呼ぶデータ項目の 仕様策定作業が進んでいる。これは筆者が取りまと めを担当しており，今後IMS Caliperと整合性を取る ため，調整の電話会議が開催される予定である。

\section{9 教師用指導書}

学習者が用いる教科書のほかに，各国の教科書会
社は教師用の冊子を作成・配布している。日本の検 定教科書では，教師用指導書として研究編と朱書編 が発行されている。これらをEDUPUBコミュニティー ではTeachers' GuidebookとTeachers' Editionと呼んで 区別している。

このうち，特にTeachers' Editionは学習者用の教科 書との重複記述が多く，また学習目標，追加問題， 評価基準など, Teachers' Edition特有の項目がある（図 1 (h))。このため，これらの項目を意味的に区別する ためのタグを，3.2のタグとは別に規定する必要があ る。

このタグは，現在筆者がIDPFに対して予備的な仕 様を提案しており，今後議論が始まると予想される。

\subsection{0 参考書等との相互参照}

教科書は，それのみで学習活動の場で使われるこ とは少なく，参考書や辞書などの教材と相互参照さ れて使われる場合が多い（図1 (i))。電子教科書を用 いる場合，同様の相互参照が必要となるが，これを どのように実現するかはまだEDUPUBでは議論されて いない。一案としては，参考書や辞書を教科書と異 なるアプリ上で閲覧できるようにし，IMS LTI規格を 用いて相互参照する，という実現方法がある。その 一方で，参考書や辞書も電子書籍としてビューアー 上に表示し，切り替え，あるいはオーバーラップさ せて表示させるという方法もある。ただし，後者で の相互参照の方法はまだ議論されておらず，今後の 議論を待つ必要がある。

\section{4. おわりに}

本稿では，電子教科書を標準規格の観点から述べ た。3章で述べたEDUPUBの多くの部分は，現在議論 が進行している段階であり，今後変更される可能性 がある。しかし，これほど多くの機能について，実 現可能性を踏まえた形で議論されている規格はほか にない。 
日本でも，文部科学省がEPUB3，総務省がHTML5 をべースとした電子教科書の仕様を議論している 段階である。この議論や，今後公開される仕様が， 電子教科書のグローバルなフォーラム標準である
EDUPUBと可能なかぎり整合させ，1章で述べた規格 標準化のメリットを享受できるよう，筆者としても 努力していきたい。

\section{本文の注}

注1）知的財産戦略本部 知的創造サイクル専門調査会 第6回 参考資料 1 : 国際標準に関する基礎概念の整理. 首相官邸, http://www.kantei.go.jp/jp/singi/titeki2/tyousakai/cycle/dai6/6sankou1.pdf

注2） 総務省研究開発・標準化戦略委員会. ICT国際標準化推進ガイドライン, http://www.soumu.go.jp/ main_sosiki/joho_tsusin/policyreports/joho_tsusin/sokai/pdf/080627_3_si19-4-2-bt5.pdf

注3) IEEE, https://www.ieee.org/

注4) IDPF (International Digital Publishing Forum), http://idpf.org/

注5) ADL, Experience API, http://www.adlnet.gov/tla/experience-api/

注6) Richards, T. et al., The IEEE Actionable Data Book and EPUB3, http://www.slideshare.net/JohnBCosta/ adb-brief-for-edupub-2014/

注7) CEN (European Committee for Standardization), https://www.cen.eu/

注8) eTernityプロジェクト,http://www.eternityproject.eu/

注9) IMS GLC, http://www.imsglobal.org/

注10) EDUCAUSE, http://www.educause.edu/

注11)ICEプロジェクト, http://www.imsglobal.org/icecallforParticipation.html

注12) W3C (World Wide Web Consortium), http://www.w3.org/

注13) EDUPUB Workshop in Boston, http://idpf.org/edupub-2013/

注14) EDUPUB Workshop in Salt Lake, http://www.imsglobal.org/edupub/

注15) EDUPUB Workshop in Oslo, http://idpf.org/edupub-europe-2014/

注16) EDUPUB Workshop in Tokyo, http://www.jepa.or.jp/edupub/

注17) IDPF, EPUB3 EDUPUB Profile, http://www.idpf.org/epub/profiles/edu/spec/

注18) Dublin Core Metadata Initiative, http://dublincore.org/

注19) ISO 15836: Information and Documentation - The Dublin Core metadata element set, http://www.iso. org/iso/iso_catalogue/catalogue_tc/catalogue_detail.htm?csnumber=37629

注20) 1484.12.1-2002 - IEEE Standard for Learning Object Metadata, http://standards.ieee.org/findstds/ standard/1484.12.1-2002.html

注21) IMS Learning Resource Meta-data, http://www.imsproject.org/metadata/

注22) Learning Resource Metadata Initiative, http://www.Irmi.net/

注23) IDPF, EPUB Multiple-Rendition Publications, http://www.idpf.org/epub/renditions/multiple/

注24) W3C, Open Annotation Data Model, http://www.openannotation.org/spec/core/ 
注25) IDPF, Open Annotation in EPUB, http://www.idpf.org/epub/oa/

注26) IMS, Learning Tools Interoperability, http://www.imsglobal.org/toolsinteroperability2.cfm

注27) IMS, Question \& Test Interoperability Specification, http://www.imsglobal.org/question/

注28) IMS, Caliper Analytics, http://www.imsglobal.org/caliper/

\section{参考文献}

1）田村恭久. 電子教科書の現状. 情報管理. 2014, vol. 57, no. 5, p. 307-314.

2）金正勲. 技術標準化，パテントプール，そして競争政策. 平成15年度産業財産権研究推進事業報告書. 2004.

3）村田真. 電子書籍フォーマットEPUBと日本語組版：日本でメインストリームにいる人間は国際標準化の 舞台ではまず勝てない. 情報管理. 2012, vol. 55, no. 1, p. 13-20.

4）高瀬拓史. EPUB概説：電子出版物とWeb標準. 情報管理. 2014, vol. 57, no. 9, p. 618-628.

5) Arenas, E.; Richards, T.; Barr, A. The IEEE Actionable Data Book: A platform for inclusive education, Proc. Global Humanitarian Technology Conference (GHTC), p. 63-67, 2013.

\section{Author Abstract}

This article introduces various activities to develop specifications of digital textbooks, including overview of EDUPUB specification. Standard specification will bring advantages both to developer side and user side. Currently, IEEE, CEN and IMS are trying to develop their specifications of digital textbooks, but the most influential one is called EDUPUB by IDPF, IMS and W3C. All draft specifications are open, so all stakeholders are able to reflect their own opinions and develop their own products based on the specification. EDUPUB discussions are still ongoing, so their contents are subject to change and enhance in the near future.

Key words

EDUPUB, digital textbook, standard specification, community standard, IDPF, IMS GLC, W3C, IEEE, CEN 